\title{
TECHNO-ECONOMIC ANALYSIS OF SOLAR ENERGY USE FOR SANITARY WATER HEATING IN INSTITUTE "DRIN FOJNICA"
}

\author{
Esmina Šahić, Azrudin Husika, Nurin Zečević \& Ejub Džaferović
}
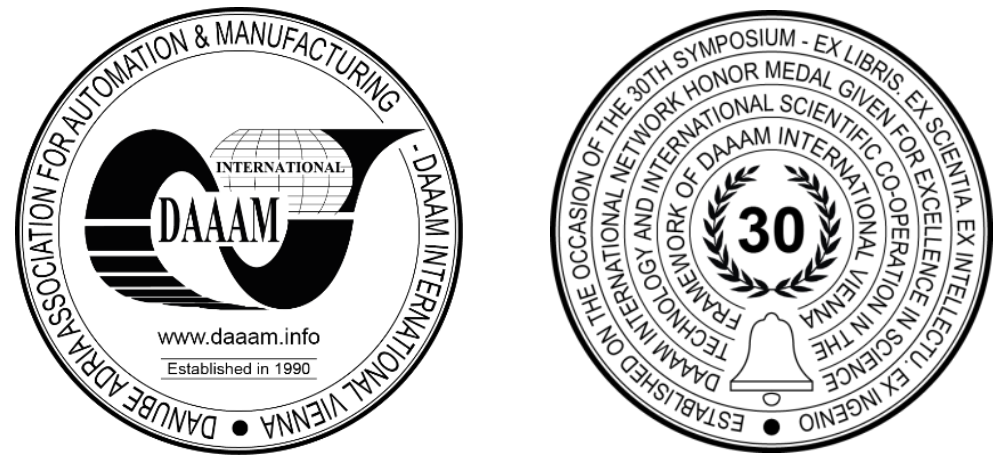

This Publication has to be referred as: Sahic, E[smina]; Husika, A[zrudin]; Zecevic, N[urin] \& Dzaferovic, E[jub] (2020). Techno-Economic Analysis Solar Energy Use for Sanitary Water Heating in Institute ""Drin Fojnica"", Proceedings of the 31st DAAAM International Symposium, pp.0542-0549, B. Katalinic (Ed.), Published by DAAAM International, ISBN 978-3-902734-29-7, ISSN 1726-9679, Vienna, Austria DOI: $10.2507 / 31$ st.daaam.proceedings.075

\begin{abstract}
The paper analyses the impact of installation of the solar heat system in the building of the Institute for Care of Mental Disabled Persons „Drin Fojnica” on its energy consumption, energy costs and air emissions. During 2019, solar collectors were installed on the roof of the Institute's main building, as a support for heating of hot sanitary water (HSW). Heating of HSW before installation of solar heat system was performed by the electric boilers out of heating season and by heat from the coal boiler during heating season. This way of HSW heating caused high energy costs for the Institute. Since there was no data on baseline energy consumption for HSW heating, the calculation of heat demand for HSW was performed based on the number of users and water consumption per user. Based on the calculation of heat production from the solar collectors and secondary heat sources for HSW (out of heating season the electric boilers, during the heating seasons the coal boiler) the annual energy balance of the system for HSW was obtained. The energy balance was the basis for calculation of decrease of coal and electricity consumption, annual cost savings for heating of HSW, financial indicators of investment in the solar system (payback period, net present value and internal return rate), reduction of air pollutant emissions (sulphur dioxide, nitrogen oxide and particulate matter) and carbon dioxide. Financial savings achieved by the solar system amount is about 8,500 BAM per year. Direct emissions of air pollutants were reduced by $27.12 \%$ and indirect by $29.02 \%$. The payback period is 5.8 years.
\end{abstract}

Keywords: solar collectors; hot sanitary water; public buildings; savings; air emissions.

\section{Introduction}

The largest consumer of energy in Bosnia and Herzegovina $(\mathrm{BiH})$ is the building sector, which includes households and facilities that provide public and commercial services, with the consumption of $55 \%$ of total energy. In developed countries, this consumption is about $40 \%$, but due to the lower industry consumption, the share of buildings in $\mathrm{BiH}$ is higher. Particularly strong barriers to the implementation of energy efficiency programs exist exactly in a sector of public services. More efficient energy consumption in public buildings, as a direct consequence has the opening of the new investment opportunities through reduced budget allocations for management costs in such facilities. The saved funds can be further distributed to other, priority areas of general social interest. 
Furthermore, with the successful implementing of energy efficiency program in their own facilities, i.e. in buildings of public sector, cantons, cities and municipalities are sending the message that energy efficiency is not only proposing to someone else, but also implements in the "own home".

In this way, more efficient use of energy will be encouraged, in energy consumption of the fastest growing sectors, households, but also in other subsectors of general consumption, especially agriculture, in which energy efficiency as a measure for improvement of competitiveness of agricultural production is still not recognized [1]. According to the estimation for 2012, in $\mathrm{BiH}$ for residential sector was spent $28 \%$, industry $16 \%$, commercial and public services $6 \%$, transport $33 \%$ and others $17 \%$ of total final energy consumption [2]. Thus, the share of residential sector and transport in energy consumption is the largest. The energy consumed in residential sector is used for space heating (most of the part), preparation of hot sanitary water, cooking, lighting, operation of appliances and equipment.

$\mathrm{BiH}$ is characterized as a country with very low efficiency in residential, public and industrial sector. Country spends about $20 \%$ of its GDP on energy, which is three times higher than in countries of EU and the US [3]. In the cycle of production, distribution and energy consumption in $\mathrm{BiH}$ large losses are achieved. The same energy amount generates four time less GDP than in the average country of EU, and twice as much environmental pollution. Disproportionate exploitation of coal causes higher degree of pollution and economic loss, the distribution of heating energy records an additional loss and finally, the use of energy in households and public sector is extremely inefficient [4].

For preparation of HSW in BiH electricity has predominantly been used. In a small number of cases, HSW is being prepared through central heating system. Thermal energy from the district heating network is used only for space heating, not for preparation of HSW, but projects for this type of energy use are also being developed. A new trend in the field of energy in the long term utilization resources is the use of renewable resources, meaning for example the energy hydro, wind, solar and geothermal. Using energy produced by renewable energy sources mentioned above no harmful emissions appear, and thus such resources do not contribute to greenhouse gases.

It slows the depletion of non-renewable resources and also helps the formation new job opportunities. Energy from the sun can be used in several ways. Currently, the most widespread energy production using solar panels with a photovoltaic phenomenon and solar radiation is directly converted into electrical energy [5]. The use of solar energy in preparation of HSW and space heating can decrease consumption of conventional energy sources and reduce environmental pollution with pollutants. The amount of produced energy is then influenced by the intensity of solar radiation in the location and time that the radiation falls on the surface of the panel [5]. Intensity of solar radiation is versatile, depending on the season, meteorological conditions and geographical location. In order for hot water to be available throughout the year, it is common to use solar energy in combination with another energy source that is used when solar energy is not enough to reach desired temperature of the water. On average, these systems reduce the consumption of heating oil or other energy sources by two-thirds, thus reducing costs and adverse environmental impacts [6].

Financial viability of solar heat project depends on many factors such as curve of heat demand during a year, solar radiation at a location, price of baseline energy, subsidies etc. Few solar heat projects have been implemented in BiH so far. Therefore, there is lack of data on financial viability of such projects. The purpose of the paper is to analyze financial viability and environmental benefits of solar heat collectors installed on public buildings in BiH for heating of HSW. Analysis is based on calculation of viability and benefits. Taking into account that the heat collectors have been operating since January 2020, obtained results can be compared with achieved financial savings at the beginning of 2021. Difference between calculated and achieved savings can be served for improvement of reliability of analysis of feasibility of solar heat application project in preparation phase in $\mathrm{BiH}$. Recently, there are no subsidies for solar heat technologies in $\mathrm{BiH}$. Calculated financial viability and environmental benefits can be served for determination of adequate level of subsidies for solar heat projects.

\section{Analysis of solar energy potential}

Most forms of energy on Earth are origin from solar radiation. The use of solar energy reduces the need for fossil fuels and reduces environmental pollution caused by their combustion. Solar energy does not produce greenhouse gases that cause global warming and radioactive waste. The total solar energy absorbed in the Earth's atmosphere, oceans and land masses is approximately 3,850,000 EJ per year. In one hour, Sun gives more energy than all humanity can spend during one year. Photosynthesis captures approximately 3.000 EJ per year in biomass. Amount of solar energy that reaches Earth's surface is so great that it is twice of total energy that humanity will ever obtain from all non-renewable sources of coal, oil, natural gas and excavated uranium, together [7].

The average solar radiation in the Balkan countries is about $40 \%$ higher than the European average, but despite that, the use of solar energy lags far behind EU countries. Creating opportunities for development and functionality of a sustainable market for solar system is of great importance for economy and environmental protection in $\mathrm{BiH}$. In $\mathrm{BiH}$, values of average daily amount of radiation on the horizontal surface ranges from $3.4 \mathrm{kWh} / \mathrm{m}^{2}$ (Bosanski Brod) to 4.22 $\mathrm{kWh} / \mathrm{m}^{2}$ (Trebinje), i.e. between 1,241 and $1,540 \mathrm{kWh} / \mathrm{m}^{2}$ per year. The duration of insolation, i.e. average number of sunny hours per year is about 2,400 hours. For comparison, average value of daily radiation amount on horizontal surface in Denmark, a country that is leading in the use of solar technologies in district heating systems in Europe, is about 4.5 $\mathrm{kWh} / \mathrm{m}^{2}$ [8]. 


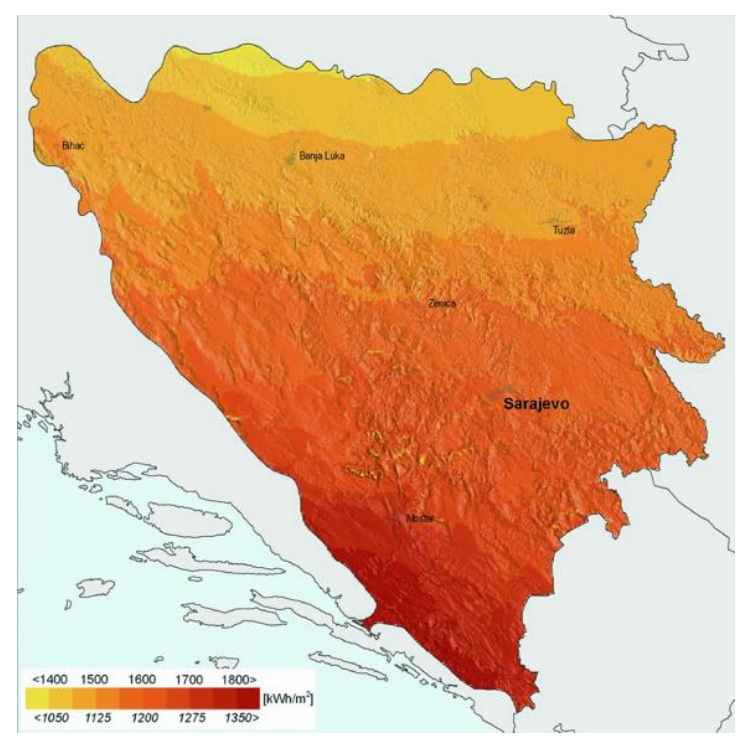

Fig. 1. Annual amount of total horizontal radiation of the Sun in the territory of $\mathrm{BiH}$ [8]

From all collected data and conducted analysis, it can be concluded that in Bosnia and Herzegovina there is significant potential for the use of solar energy, which amounts 70.5 million GWh of irradiated energy of total solar radiation per year. Figure 1 shows the changes of total horizontal radiation of the Sun in some parts of $\mathrm{BiH}$ [8]. Solar collectors as such are increasingly used in large plants, but also the owners of public buildings have seen the benefits of installation of solar collectors.

\section{Benefits of using solar collectors for heating of hot sanitary water in Institution "Drin Fojnica "}

Public buildings, whose users need HSW, throughout the year on a large scale are optimal for application of solar thermal systems. Institute for the Care of Mentally Disabled Persons „Drin Fojnica“ has about 500 users, of which 320 are housed in the facility. The Institute works 24 hours a day, seven days a week, during all year. Initially, the preparation of HSW was performed by electric boilers out of heating season and during the heating seasons by the coal boiler. This way of HSW heating caused high energy costs and increase of air pollution during the winter especially. These were the main driving force for installation of solar heat collectors for HSW heating. Based on the number of users and HSW demand per user, calculation of heat needs for HSW was calculated using the following equation:

$$
Q_{w}=4.182 \cdot V_{w, f, d a y} \cdot f\left(t_{w, d e l}-t_{w, o}\right) \frac{d}{3600}
$$

Where:

$V_{w, f, d a y}-\mathrm{HSW}$ demand per user for one day (50 $\left.\frac{l}{u s e r}\right)$ is used for calculation)

$f$ - number of users for HSW needs (320 is used for calculation)

$t_{w, \text { del }}$ - required temperature for heating tap water $\left(45^{\circ} \mathrm{C}\right.$ is used for calculation)

$t_{w, o}-$ inlet water temperature $\left(12{ }^{\circ} \mathrm{C}\right.$ is used for calculation)

$d$-number of days when hot sanitary water is required (365 is used for calculation)

By including the values in (1), the energy demand for HSW was calculated, which amounts $223,876 \mathrm{kWh}$ per year.

During 2019, on the roof of the Institute's main building, system of solar collectors was installed as a support for the preparation of HSW. Collectors were installed on the roof that is southeast oriented. System is consisted of 16 plate solar collectors with gross collector surface of $2.5 \mathrm{~m}^{2}$ per collector. The total absorber area is $38 \mathrm{~m}^{2}$. At the end of December 2019, the system was put into operation. With installation of this system, the energy mix for heating of HSW has been changed. HSW now is heated by solar energy in the period of heating season, in combination with the energy from the coal boiler, while in the period out of heating season, HSW is heated by a combination of solar energy and electricity.

\subsection{Energy balance and cost savings for heating of HSW due to installation of solar collectors}

Before installation of solar collectors, for HSW heating, the coal boiler was being used for 182 days and electricity for 183 days in a year. The annual energy demand from coal to provide heat for HSW was calculated by the following equation: 


$$
Q_{\text {coal }}=\frac{Q_{W}}{2 \eta}
$$

Where:

$\eta$ - the total efficiency rate of transformation of energy in coal into heat for HSW, which is 0.68 [9].

To meet the needs on an annual level, 164,615 kWh from coal is needed. The calorific value of the coal is 15,000 $\mathrm{kJ} / \mathrm{kg}$ [9]. The annual energy consumption of coal to produce the necessary heat for HSW was calculated by the following equation:

$$
B_{\text {coal }}=\frac{Q_{\text {coal }}}{H_{d}}
$$

Where:

$H_{d}$ - calorific value of the coal. 39.50 tons of coal are needed to meet the needs at an annual level for HSW heating. Annual electricity demand for HSW heating was calculated by the following equation:

$$
Q_{e}=\frac{Q_{w}}{2}
$$

$112,552 \mathrm{kWh}$ of electricity is needed to meet the needs at an annual level for HSW heating.

The price of the coal (160 BAM/t) and electricity (0.2 BAM/kWh) was taken from detailed energy audit of Institute [9]. The energy costs for HSW heating were calculated using the following expression:

$$
C=C_{\text {coal }} \cdot B_{\text {coal }}+C_{e} \cdot Q_{e}
$$

Before installation of solar collectors, energy costs for HSW heating were 28,831 BAM per year.

The solar energy that is utilized for HSW heating was calculated based on the seasonal insolation (Table 1), the total collectors' area of $38 \mathrm{~m}^{2}$ and collector efficiency rate of $80 \%$. The annual heat generated from the collectors is 52,522 $\mathrm{kWh}$.

\begin{tabular}{|c|c|c|c|}
\hline Month & Days & $\mathbf{H}_{\mathbf{d}}$ & $\begin{array}{c}\text { Monthly } \\
{[\mathbf{k W h}]}\end{array}$ \\
\hline Jan. & 31 & 2.376 & 2,267 \\
\hline Feb. & 28 & 3.228 & 2,782 \\
\hline Mar. & 31 & 4.548 & 4,340 \\
\hline Apr. & 30 & 5.436 & 5,020 \\
\hline May & 31 & 6.036 & 5,759 \\
\hline Jun. & 30 & 6.084 & 5,618 \\
\hline Jul. & 31 & 6.78 & 6,469 \\
\hline Aug. & 31 & 6.528 & 5,441 \\
\hline Sep. & 30 & 5.892 & 4,225 \\
\hline Oct. & 31 & 4.428 & 2,471 \\
\hline Nov. & 30 & 2.676 & 2,471 \\
\hline Dec. & 31 & 1.992 & 1,901 \\
\hline \multicolumn{3}{|c|}{ Total for year } & $\mathbf{5 2 , 5 2 2}$ \\
\hline
\end{tabular}

Table 1. Heat production from solar system

Based on the heat demand for HSW heating, parameters of solar system and insolation of the given location, monthly share of heat demand for HSW from solar system was calculated using the following equation:

$$
S_{i}=\frac{Q i n s_{i}}{Q m i}
$$


Where:

$S_{i}$ - share of solar heat for HSW heating for a month (\%),

Qins $_{i}$ - heat generation from solar collectors for a month $(\mathrm{kWh})$,

$Q m i$ - heat demand for HSW heating in a month $(\mathrm{kWh})$.

Share of solar heat in heat demand for HSW heating per month is given in Figure 2.

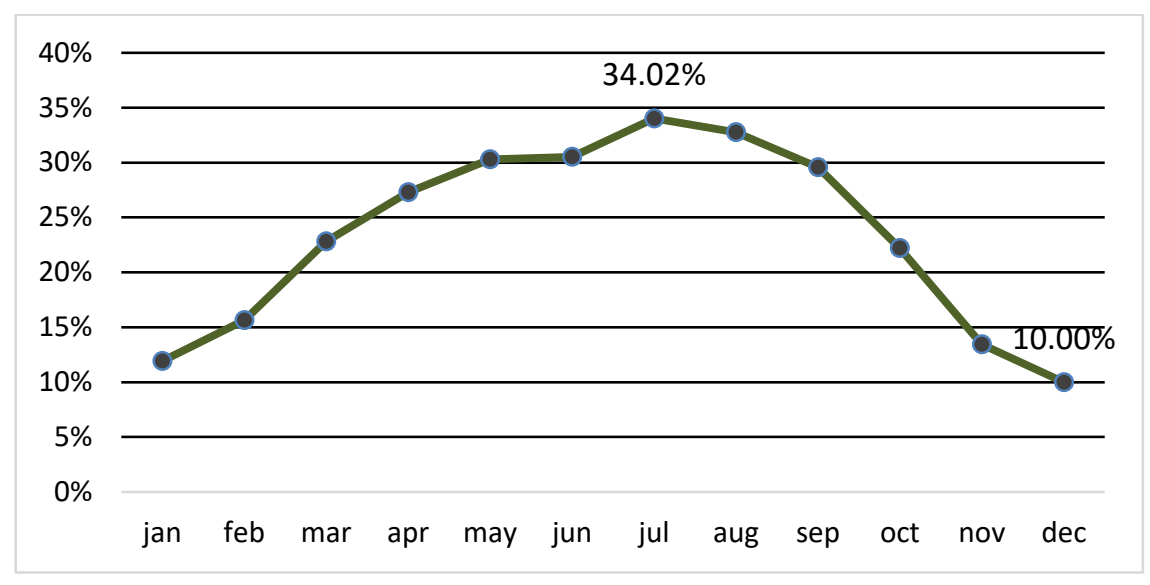

Fig. 2. Share of solar heat in heat demand for HSW heating per month

As it can be seen on figure 2, the highest share of solar heat is $34.2 \%$ in July while the lowest solar share is $10 \%$ in December. Based on the monthly solar heat share and secondary heat sources for HSW heating (out of the heating season the electrical boilers and during heating season the coal boiler) the annual energy balance of HSW heating system was obtained. Energy balance represents basis for calculation of annual cost savings for heating of HSW. Annual energy from coal, after installation of solar collectors was calculated by expression:

$$
Q_{\text {coal }}=\frac{Q_{w}}{2 \eta}-Q_{\text {sol } 1}
$$

Where:

$Q_{\text {sol1 }}$ - heat production from solar collectors during heating season $(\mathrm{kWh})$, it is obtained by summing the heat from solar collectors for months November, December, January, February, March, and half of the value for October and April (from Table 1). By including the value in (7), energy from coal for HSW heating after the installation of solar collectors was obtained and it amounts $119,974 \mathrm{kWh}$. The consumption of coal required to produce the necessary heat for HSW heating after instalation of solar collectors was calculated by the following equation:

$$
B_{g^{\prime}}=\frac{Q_{\text {coal }}}{H_{d}}
$$

Coal consumption after installation of solar collectors amounts 28.79 tons annually, which is for 10.71 tons per year less than before the installation of solar collectors.

Annual consumption of electricity after installation of solar collectors was calculated by the following equation:

$$
Q_{e^{\prime}}=\frac{Q_{w}}{2}-Q_{s o l 2}
$$

Where:

$Q_{\text {sol2 }}$ - heat production from solar collectors out of heating season, kWh.

Annual electricity required after the installation of solar collectors is $78,413 \mathrm{kWh}$, which is $34,139 \mathrm{kWh}$ less per year compared to the situation before installation of solar collectors. Based on the prices and reduction in coal and electricity consumption, the costs savings achieved by installation of solar collectors were calculated by the following equation:

$$
\Delta C=\Delta C_{\text {coal }}+\Delta C_{e}
$$


Where:

$\Delta C_{\text {coal }}$ - costs savings obtained by reduction of coal consumption and $\Delta C_{e}-$ costs savings obtained by reduction of electricity consumption.

By including values in (10), the total annual costs savings of 8,542 BAM were obtained.

\subsection{Environmental benefits of using solar collectors}

Based on savings of energy, obtained by reduction of coal consumption and emission coefficient taken from CORNIAIR base, reduction of pollutant emissions was calculated. Coefficients from CORINAIR base are given in Table 2. Emission coefficients for district heating plants have been chosen, considering that the power of the boiler is approximately to the size of boilers in district heating plants.

\begin{tabular}{|c|c|c|c|c|}
\hline \multirow{2}{*}{ Fuel } & Technology & \multicolumn{3}{|c|}{ Coefficient (g/GJ) } \\
\cline { 3 - 5 } & & $\mathrm{NO}_{\mathrm{x}}$ & $\mathrm{SO}_{\mathrm{x}}$ & $\mathrm{PM}$ \\
\hline \multirow{2}{*}{ Coal } & District heating boiler & 180 & 1,800 & 80 \\
\cline { 2 - 5 } & Furnace & 158 & 1,800 & 261 \\
\hline
\end{tabular}

Table 2. Pollutant emission coefficients [10]

Emissions were calculated by multiplying the corresponding emission coefficient with the coal energy content. The calculation of the annual reduction of sulphur dioxide emissions is presented below by the equation (11).

$$
\Delta S O_{2}=\Delta B_{\text {coal }} \cdot H_{d} \cdot c
$$

Where:

$\Delta B_{\text {coal }}$ - annual reduction of coal consumption (t/a),

$H_{d}-$ calorific value of coal $(\mathrm{GJ} / \mathrm{t})$,

$\mathrm{c}$ - emission coefficient $(\mathrm{g} / \mathrm{GJ})$.

By including the values in (11), annual reduction in sulphur dioxide emissions of $289.25 \mathrm{~kg}$ was obtained. Reduction in nitrogen oxide and particulate matter emissions were calculated in the same way (presented in table 3). Reduction of carbon dioxide was calculated based on calculated reduction of electricity consumption and electricity power network coefficient for carbon dioxide (indirect emissions) and reduction of coal consumption and coal emission coefficient for carbon dioxide (direct emissions). Reduction of carbon dioxide emissions due to the reduction of electricity consumption was calculated by the following equation:

$$
\Delta C O_{21}=e_{\mathrm{CO}_{2}} \cdot \Delta E
$$

Where:

$e_{\mathrm{CO}_{2}}$ - power network coefficient for carbon dioxide, for $\mathrm{BiH}$ it is $720 \mathrm{~kg} / \mathrm{MWh}$ [11].

$\Delta E-$ reduction of electricity consumption (MWh/a)

Reduction of carbon dioxide emissions due to the reduction of coal consumption was calculated by the following equation:

$$
\Delta C \mathrm{O}_{22}=\Delta Q_{\text {coal }} \cdot c_{\mathrm{CO}_{2}}
$$

Where:

$\Delta Q_{\text {coal }}$ - reduction of energy consumption from coal $(\mathrm{kWh} / \mathrm{a})$,

$c_{\mathrm{CO}_{2}}$ - emission coefficient of coal for carbon dioxide $\left(0.338923 \mathrm{kgCO}_{2} / \mathrm{kWh}\right.$ is used for calculation) [9]. The total reduction of carbon dioxide emissions was calculated by equations (12) and (13). It amounts 39.71 tons per year. An overview of the total reduction of emission of pollutants is presented in Table 3.

Assuming that the car emits an average $120 \mathrm{~g} / \mathrm{km}$ of carbon dioxide and exceeds $10,000 \mathrm{~km}$ per year, by implementation of the solar collectors for HSW heating, reduction of carbon dioxide emissions equivalent to the emissions of about 30 cars has been achieved. 


\begin{tabular}{|c|c|c|c|c|}
\hline Pollutant & NO $_{\mathbf{x}}$ & SO $_{\mathbf{x}}$ & $\mathbf{P M}$ & $\mathrm{CO}_{2}$ \\
\hline & $\mathrm{kg} / \mathrm{a}$ & $\mathrm{kg} / \mathrm{a}$ & $\mathrm{kg} / \mathrm{a}$ & $\mathrm{t} / \mathrm{a}$ \\
\hline Before installation of solar collectors & 106.66 & $1,066.62$ & 47.41 & 136.83 \\
\hline After installation of solar collectors & 77.74 & 777.37 & 34.55 & 97.12 \\
\hline Absolute reduction & 28.92 & 289.25 & 12.86 & 39.71 \\
\hline Percentage reduction & 27.12 & 27.12 & 27.12 & 29.02 \\
\hline
\end{tabular}

Table 3. The overview of the reduction of pollutant emissions

By comparing the average emissions from one household, that amount: $\mathrm{NO}_{\mathrm{x}} 6 \mathrm{~kg} / \mathrm{a}, \mathrm{SO}_{2} 118 \mathrm{~kg} / \mathrm{a}$ and PM $33 \mathrm{~kg} / \mathrm{a}$, with reduction of emissions achieved by the solar collectors system, it can be noticed that the reduction of sulphur dioxide emissions is equivalent to emissions from 2 households, reduction of nitrogen oxide emissions is equivalent to emissions from 4 households and reduction of particulate matter emissions is equivalent to reduction of emissions from 3 households [12].

\subsection{Costs saving analysis of installing solar collectors}

Within the cost saving analysis the following financial indicators of an investment in the solar system were calculated: simple payback period (SPB), net present value of investment (NPV) and internal rate of return (IRR). The amount of investment is taken from the priced bill of mechanical engineering works that amounts $I=49,775$ BAM.

As it was calculated in Chapter 3.1, total annual financial savings amount to $\Delta C=8,542 K M$, so SPB is:

$$
S P B=\frac{I}{\Delta C}
$$

Payback period of investment is 5.8 years, which is considered as very profitable investment.

For calculation of NPV, the lifetime of collectors is assumed to be 20 years and the same annual amount of savings for that period. Annual discount rate of $5 \%$ is used. NPV is calculated by following expression:

$$
N P V=\sum_{t=1}^{n} \frac{F_{t}}{\left(1+\frac{p}{100}\right)^{t}}-I
$$

Where:

$n$ - lifespan of solar collectors

$F_{t}$ - annual savings

$t$ - year in lifetime

$I$ - amount of investment

$p$-discount rate.

NPV is 53,524 BAM. IRR is the amount of discount rate at which the value of NPV is zero. In the case of the analysed project, it is $15.7 \%$. In Table 4 financial investment indicators are given.

\begin{tabular}{|c|c|c|c|c|c|}
\hline & Savings for HSW & Investment & SPB & IRR & NPV \\
\hline \multirow{2}{*}{$\begin{array}{c}\text { Solar collectors system } \\
\text { for HSW heating }\end{array}$} & BAM/a & BAM & year & $\%$ & BAM \\
\cline { 2 - 6 } & 8,542 & 49,775 & 5.8 & 15.7 & 53,524 \\
\hline
\end{tabular}

Table 4. Financial indicators of investment for solar collectors system for HSW heating

\section{Conclusion}

Aim of this paper is to analyse cost-effectiveness and reduction of pollutant emissions by installing the system of solar collectors for HSW heating in the building of Institute "Drin Fojnica". Institute has 500 users and 320 are housed in the building that is the subject of analysis. For HSW heating, coal and electricity were used. 
For that purpose, 39.5 tons of coal and $112,551.56 \mathrm{kWh}$ of electricity were initially needed annually. This way of HSW heating has caused a high off-season heating costs and air pollution during the heating season. The aim of installing solar collectors was to reduce costs and air pollution.

A system of solar collectors with an absorber area of $38 \mathrm{~m}^{2}$ has been installed. The investment amount was 49,775 BAM. After installation of the solar collectors, 28.79 tons of coal and 78,412.91 kWh of electricity are needed annually. The analysis showed that significant savings has been achieved in coal and electricity consumption. Coal consumption has been decreased compared to the previous situation without solar collectors by $27 \%$, while electricity consumption has been decreased by $30 \%$.

The highest share of solar heat in HSW heating is 34.02\% in July, while the lowest solar share is $10 \%$ in December. This ratio of the coverage degree is favourable from the aspect of cost reduction because electricity consumption for HSW heating is reduced during the summer months. As it was expected, financial savings are greatest during the summer months due to the higher insolation, and also because solar energy replaces electricity, which is about 3 times more expensive than energy from coal. However, the environmental benefit is more significant in the winter because coal consumption is reduced, which is a significant source of pollutant emissions in the period when the air is highly polluted.

Savings achieved with the given system amount to 8.542 BAM per year and SPB of the investment is 5.8 years, which is acceptable for private sector. Reduction of carbon dioxide emissions is equivalent to emissions from about 30 cars. Reduction of sulphur dioxide emissions is equivalent to emissions from 2 households, reduction of nitrogen oxide emissions is equivalent to emissions from 4 households and reduction of particulate emissions is equivalent to emissions from about 3 households.

Limitations of the analysis were lack of some input data for calculation of energy savings. Namely, there is no data on baseline energy consumption for HSW. For purpose of this analysis, baseline energy consumption was calculated by assuming efficiency of the coal boiler and estimating HSW demand based on the number of users and HSW demand per user. Recommendation is to install separate measurement device for electricity consumed for HSW and device for measurement of heat consumed for HSW. Utilized heat from solar collectors was calculated by assuming solar radiation and efficiency of the system. Reliability of analysis can be significantly improved by installation of device for measurement of heat gained from solar system.

Taking into account that the heat collectors have been operating since January 2020, obtained results will be compared with achieved financial savings. Difference between calculated and achieved savings will be served for improvement of reliability of analysis of feasibility of solar heat application projects in preparation phase in $\mathrm{BiH}$.

\section{Literature}

[1] Morvaj, Z.; Čačić. G. \& Nanasi, J. (2011). Priručnik za upravljanje energijom u gradovima, kantonima i općinama (Handbook for energy management in cities, cantons and municipalities), United Nation Development Program in $\mathrm{BiH}$, Bosnia and Herzegovina

[2] Gvero, P. M. (2013). National analysis of energy use for cooling and potential of solar assisted cooling in public, hotel and tourist, agriculture and service sector, Adriacold Project $2^{\circ}$ ord./0030/1, Banja Luka, Bosnia and Herzegovina

[3] Kardaš, D.; Gvero P.; Delalić, N. A. \& Rodić, S. (2015). Sistemsko upravljanje energijom u Bosni i Hercegovini (Systemic energy management in Bosnia and Herzegovina), Proceedings of symposium Energy efficiency ENEF, Banja Luka, Bosnia and Herzegovina, pp. 87-91

[4] Center for policy and governance (2011). Upravljanje energetskim sektorom i siromaštvom u Bosni i Hercegovini (Energy Sector and Poverty Management in Bosnia and Herzegovina), Sarajevo, Bosnia and Herzegovina

[5] Krpal, O.; Sirucek, M. \& Mraz, P. (2012). Influence of Renewable energy on power transformer insulating system, Proceedings of the 23rd International DAAAM Symposium, Volume 23, No.1, pp. 569-574, Vienna, Austria

[6] Dović, D. (2010). Uporaba Sunčeve energije za grijanje vode, prostora i proizvodnju električne energije (Use of solar energy for heating of water and space and electricity production), University of Zagreb, Zagreb, Croatia

[7] Luo, F.L. \& Ye, H. (2013). Renewable Energy Systems, Advance Energy Technologies and Applications, CRC Press, Taylor and Francis Group, ISBN: 978-1-4398-9109-4

[8] CETEOR (2018). Studija o obnovljivim izvorima energije s fokusom na biomasu, geotermalnu energiju i solarnu energiju u Bosni i Hercegovini (Study on renewable energy sources with a focus on biomass, geothermal energy and solar energy in Bosnia and Herzegovina), United Nation Development Program in BiH, Bosnia and Herzegovina

[9] CETEOR (2014). Detaljni energetski pregled Zavoda "Drin" Fojnica (Detailed Energy Audit of the Institute "Drin" Fojnica), UNDP, Bosnia and Herzegovina

[10] European Environment Agency (2016). Air Pollutant Emission Inventory Guidebook: Technical guidance to prepare national emission inventories, EEA Report 21/2016, ISSN 1977-8449

[11] UNDP (2016). III Nacionalni izvještaj i drugi dvogodišnji izvještaj o emisiji stakleničkih plinova Bosne i Hercegovine (National Report and Second Biennial Report on Greenhouse Gas Emissions of Bosnia and Herzegovina), United Nation Development Program in BiH, Bosnia and Herzegovina

[12] Husika, A. (2020). Kvalitet zraka u Kaknju. Kako dalje? (Air Quality in Kakanj. How to proceed?), Mechanical Engineering Faculty University of Sarajevo, Kakanj, Bosnia and Herzegovina 